\title{
A Multiyear Record of Rainfall and lonic Composition along an Elevation Gradient in Northeastern Puerto Rico
}

\author{
Elvis Torres-Delgado ${ }^{1 *}$, Grizelle González², Ernesto Medina,3, María M. Rivera² \\ ${ }^{1}$ Department of Environmental Science, University of Puerto Rico, Río Piedras Campus, San \\ Juan, PR 00925, USA \\ ${ }^{2}$ International Institute of Tropical Forestry, USDA Forest Service, Jardín Botánico Sur, 1201 \\ Calle Ceiba, Río Piedras, PR 00926, USA \\ ${ }^{3}$ Instituto Venezolano de Investigaciones Científicas, Aptdo 21827, Caracas 1020-A, Venezuela
}

\section{ABSTRACT}

This study analyzes multiyear data recorded by 21 stations along an elevation gradient (0$1045 \mathrm{~m}$ a.s.l.) in the Luquillo Mountains on the rainfall and the rainwater chemistry. The total ionic concentration and the rainwater volume exhibited an inverse exponential relationship, with the correlation coefficients ranging from -0.66 to -0.90 . Furthermore, the rainfall tended to increase with the elevation, although a few stations, owing to their geographical location and their exposure to the prevailing winds, departed from this trend. The ionic composition also displayed clear seasonality: Contributions from African crustal aerosols and, to a lesser degree, North American anthropogenic aerosols were observed during summer and winter, respectively, whereas marine aerosols were influential year-round. Finally, the annual loads $\left(\mathrm{kg} \mathrm{ha}^{-1} \mathrm{y}^{-1}\right)$ first increased for all of the species, except $\mathrm{PO}_{4}{ }^{3-}$ and $\mathrm{K}^{+}$, from the lowland to the cloud formation levels (by 47-121\%) and then decreased for all of them, except $\mathrm{PO}_{4}{ }^{3-}$ and $\mathrm{NO}_{3}{ }^{-}$, at the altitudes above.

Keywords: Precipitation chemistry, Luquillo Experimental Forest, Rainforest hydrology, Tropical forest, Nutrient deposition

\section{OPEN ACCESS}

Received: October 1, 2020 Revised: January 29, 2021 Accepted: February 2, 2021

${ }^{*}$ Corresponding Author: elvis.torres810@gmail.com

\section{Publisher:}

Taiwan Association for Aerosol Research

ISSN: $1680-8584$ print ISSN: 2071-1409 online

(c) Copyright: The Author(s). This is an open access article distributed under the terms of the Creative Commons Attribution License (CC BY 4.0), which permits unrestricted use, distribution, and reproduction in any medium, provided the original author and source are cited.

\section{INTRODUCTION}

Wet deposition is an essential source of nutrients and pollutants for terrestrial ecosystems, such as tropical forests. The Luquillo Experimental Forest (LEF), also known as El Yunque National Forest, is a tropical forest located in the Luquillo Mountains in northeastern Puerto Rico, which elevates from the coast to an elevation of over $1000 \mathrm{~m}$ in a horizontal distance of about $8 \mathrm{~km}$ (González et al., 2013; Lugo et al., 2015), creating steep slopes within the mountain range. Due to these topographic characteristics and the trade winds that constantly influence the island, cloud formation is mainly formed through orographic ascension making the Luquillo Mountains the rainiest part of the island (García-Martinó et al., 1996; Murphy et al., 2017). Several rivers and creeks are fed from the rainfall at the Luquillo Mountains and are a vital water supply to people and other organisms.

One of the most interesting features of the Luquillo Mountains is the steep slope from the coast to its highest peak. This steep slope creates an elevation gradient that provides different biotic and abiotic conditions, such as temperature, cloud cover, and rainfall patterns. As air masses move up the slope, the temperature of the air mass decreases until water vapor condenses and falls as precipitation. Precipitation not only provides water but also pushes down atmospheric aerosols via rainout and washout processes that get deposited on the surface, and that can have considerable ecological consequences in the different ecosystems.

Since the mountains are close to the coast, marine aerosols are prominent around the area 
year round. However, distinct air masses can reach the island and alter the rain composition at different times. During summer, high concentrations of African dust can be detected in the Caribbean Basin (Prospero and Lamb, 2003; Prospero and Mayol-Bracero, 2013), including Puerto Rico, and can affect visibility and precipitation patterns. African dust travels long distances from the African continent due to the movements of the Intertropical Convergence Zone (ITCZ), which moves north toward the Caribbean region during the Northern Hemisphere summer and south towards the South American region during winter. During winter, Puerto Rico is affected by cold fronts that move from North America towards the Caribbean and drag anthropogenic pollution from the east coast of the United States (Allan et al., 2008; Valle-Díaz et al., 2016).

The Luquillo Mountains have been a place of intense multidisciplinary research for many decades (Odum, 1970; Brokaw et al., 2012). Studies involving rain characteristics and composition have been performed in several places across the mountains, some concerned with climatological patterns of precipitation and others to biogeochemical cycles (Martens and Harriss, 1973; Weathers et al., 1988; McDowell et al., 1990; Asbury et al., 1994; Heartsill-Scalley et al., 2007; Gioda et al., 2009, 2011, 2013; Medina et al., 2013). Studies assessing rain chemical composition coincide with the observation that marine air masses are the primary source of ions. Many of these studies show that crustal and anthropogenic air masses can also influence precipitation (Allan et al., 2008; Gioda et al., 2013; Medina et al., 2013; Valle-Díaz et al., 2016). Gioda et al. (2013) determined that sea salt contributed to $70 \%$ of the total ionic load, with $\mathrm{Ca}^{2+}$, a proxy for crustal air masses (McClintock et al., 2019; Stallard and Murphy, 2012), accounting for 6-8\% of the total load.

While many studies assessing precipitation chemistry at the Luquillo Mountains are available, only the study of Medina et al. (2013) focused on how it changes through the elevation gradient in this mountain range. However, that study was limited to one year of data. The objective of this study is to build on the work of Medina et al. (2013) to answer the question of how rainfall and ionic composition vary between seasons and in the elevation gradient of the Luquillo Mountains using a multiyear record of rain chemistry.

\section{METHODS}

\subsection{Sampling Sites}

The meteorological stations used for this study are located across the elevation gradient of the Luquillo Mountains (Gould et al., 2006), starting from sea level (0 m a.s.I.) to El Yunque Peak, the highest peak of the mountains (1045 $\mathrm{m}$ a.s.l.). The stations were grouped in five categories based on their elevation and distance from the coast: lowland coastal (0-100 $\mathrm{m}$ a.s.l.; LC), lowland interior (0-100 m a.s.I.; LI), lower montane (200-525 m a.s.I.; LM), cloud formation level (600800 m a.s.I.; CFL), and upper cloud formation level (900-1045 m a.s.I.; UCFL) (Medina et al., 2013). Station names, abbreviations, elevation, elevation category, and coordinates are presented in Table 1. A detailed map with the locations of the stations is included in Medina et al. (2013) and Van Beusekom et al. (2015).

\subsection{Rain Collection and Chemical Analyses}

Total rainfall was measured in 21 stations located inside and around the LEF from 2009 through 2018. Rainfall collectors were placed at a $1.45 \mathrm{~m}$ height and away from any vegetation or structure to avoid interception. The collectors are made from UV resistant polycarbonate plastic, have a capacity of $25 \mathrm{~mm}(180 \mathrm{~mL})$, and are covered with a $101 \mathrm{~mm}$ diameter funnel. The collector is placed inside a larger-capacity cylinder to capture rainwater if it gets overflown, providing for a total of $300 \mathrm{~mm}$ collection capacity. Overflown conditions over the $300 \mathrm{~mm}$ capacity were rare, and for the stations where this happened the most (MB and YPC), this only occurred for 4 out of 124 samples, representing 3\% of the data. A more detailed description of the sample collection procedure can be found in Medina et al. (2013).

For all rainwater samples, $\mathrm{pH}$ was measured on site using an EXTECH EC500 ExStik II meter starting in 2011. Only during September and October of 2017, sampling was interrupted because of the passage of Hurricane María. Means for $\mathrm{pH}$ were determined using the concentration of hydronium ion $\left[\mathrm{H}^{+}\right]$and later converting it back to $\mathrm{pH}$ values. Rainwater was measured bi-weekly, and samples for chemical analysis were collected at the end of the month corresponding to the 
Table 1. Description and geographical information of collection stations.

\begin{tabular}{|c|c|c|c|c|c|}
\hline Station name & Station ID & Elevation $(\mathrm{m})$ & Elevation site & Latitude (N) & Longitude (W) \\
\hline Palmas del Mar & PDM & 0 & Lowland coastal & $18^{\circ} 05^{\prime} 32.63^{\prime \prime}$ & $65^{\circ} 48^{\prime} 04.64^{\prime \prime}$ \\
\hline Humacao & $\mathrm{H}$ & 3 & Lowland coastal & $18^{\circ} 10^{\prime} 42.27^{\prime \prime}$ & $65^{\circ} 45^{\prime} 53.23^{\prime \prime}$ \\
\hline Sabana Seca \#2 & SS\#2 & 3 & Lowland coastal & $18^{\circ} 27^{\prime} 40.45^{\prime \prime}$ & $66^{\circ} 12^{\prime} 16.65^{\prime \prime}$ \\
\hline Las Cabezas II & LCM & 4 & Lowland coastal & $18^{\circ} 22^{\prime} 40.73^{\prime \prime}$ & $65^{\circ} 37^{\prime} 08.90^{\prime \prime}$ \\
\hline Ceiba I & CDI & 9 & Lowland coastal & $18^{\circ} 13^{\prime} 59.01^{\prime \prime}$ & $65^{\circ} 35^{\prime} 59.13^{\prime \prime}$ \\
\hline Ceiba II & CDII & 14 & Lowland coastal & $18^{\circ} 13^{\prime} 15.13^{\prime \prime}$ & $65^{\circ} 40^{\prime} 13.43^{\prime \prime}$ \\
\hline Las Cabezas I & LCD & 31 & Lowland coastal & $18^{\circ} 22^{\prime} 51.29^{\prime \prime}$ & $65^{\circ} 37^{\prime} 13.71^{\prime \prime}$ \\
\hline Ford & Ford & 13 & Lowland interior & $18^{\circ} 23^{\prime} 12.23^{\prime \prime}$ & $65^{\circ} 52^{\prime} 48.04^{\prime \prime}$ \\
\hline Jardín Botánico & $J B$ & 26 & Lowland interior & $18^{\circ} 23^{\prime} 01.35^{\prime \prime}$ & $66^{\circ} 03^{\prime} 11.30^{\prime \prime}$ \\
\hline Saint Just & SJ & 81 & Lowland interior & $18^{\circ} 23^{\prime} 04.90^{\prime \prime}$ & $65^{\circ} 59^{\prime} 58.23^{\prime \prime}$ \\
\hline Sabana 4 Bisley & S4 & 226 & Lower montane & $18^{\circ} 19^{\prime} 01.63^{\prime \prime}$ & $65^{\circ} 44^{\prime} 30.68^{\prime \prime}$ \\
\hline Sabana 4 Bisley \#2 & S4\#2 & 226 & Lower montane & $18^{\circ} 19^{\prime} 01.63^{\prime \prime}$ & $65^{\circ} 44^{\prime} 30.68^{\prime \prime}$ \\
\hline El Verde & ELV & 361 & Lower montane & $18^{\circ} 19^{\prime} 10.02^{\prime \prime}$ & $65^{\circ} 48^{\prime} 58.28^{\prime \prime}$ \\
\hline Rio Grande & RG & 525 & Lower montane & $18^{\circ} 17^{\prime} 36.83^{\prime \prime}$ & $65^{\circ} 48^{\prime} 23.47^{\prime \prime}$ \\
\hline UPR (Nido) & NIDO & 655 & Cloud formation level & $18^{\circ} 18^{\prime} 00.81^{\prime \prime}$ & $65^{\circ} 47^{\prime} 00.05^{\prime \prime}$ \\
\hline Pico del Este I - Colorado & $\mathrm{CO}$ & 778 & Cloud formation level & $18^{\circ} 17^{\prime} 38.58^{\prime \prime}$ & $65^{\circ} 47^{\prime} 11.46^{\prime \prime}$ \\
\hline El Toro & TORO & 792 & Cloud formation level & $18^{\circ} 16^{\prime} 40.06^{\prime \prime}$ & $65^{\circ} 50^{\prime} 53.26^{\prime \prime}$ \\
\hline Mount Britton & $\mathrm{MB}$ & 901 & Upper cloud formation level & $18^{\circ} 18^{\prime} 16.02^{\prime \prime}$ & $65^{\circ} 47^{\prime} 26.14^{\prime \prime}$ \\
\hline Pico del Oeste & POC & 987 & Upper cloud formation level & $18^{\circ} 16^{\prime} 39.18^{\prime \prime}$ & $65^{\circ} 45^{\prime} 51.44^{\prime \prime}$ \\
\hline Pico del Este II - Cloud & PEC & 1002 & Upper cloud formation level & $18^{\circ} 16^{\prime} 17.15^{\prime \prime}$ & $65^{\circ} 45^{\prime} 40.42^{\prime \prime}$ \\
\hline El Yunque & YPC & 1045 & Upper cloud formation level & $18^{\circ} 18^{\prime} 38.23^{\prime \prime}$ & $65^{\circ} 45^{\prime} 26.14^{\prime \prime}$ \\
\hline
\end{tabular}

last two weeks of the month. Samples were stored in $20 \mathrm{~mL}$ plastic bottles and transported in ice from the field to the chemistry laboratory at the International Institute of Tropical Forestry in Río Piedras, Puerto Rico, where they were stored at $4{ }^{\circ} \mathrm{C}$ until analysis. Ionic concentrations $\left(\mathrm{Cl}^{-}, \mathrm{Br}^{-}\right.$, $\mathrm{NO}_{3}{ }^{-}, \mathrm{SO}_{4}{ }^{2-}, \mathrm{PO}_{4}{ }^{3-}, \mathrm{Na}^{+}, \mathrm{K}^{+}, \mathrm{NH}_{4}{ }^{+}, \mathrm{Mg}^{2+}, \mathrm{Ca}^{2+}$ ) were determined using a dual-column Dionex ICS3000 ion chromatograph with a conductivity detector. Samples are injected into the system using a low-volume $200 \mu \mathrm{L}$ injection loop to enhance peak sensitivity and avoid saturation in the column, providing and accuracy and precision tolerance of $\pm 5 \%$ for each ion with a $0.1 \mathrm{ppm}$ detection limit. The dual-column set-up allows for both anions and cations to be analyzed in parallel with a separate conductivity detector for each column.

\subsection{Statistical Analyses}

Data processing and linear least-squares regression statistical analyses for addressing the relationship of ionic concentration with the amount of rainfall were performed using Igor Pro 8.0. Pearson correlation factor table presented for determining the correlation of sodium with chloride, calcium, and sulfate ions was performed using XLSTAT version 19.

\section{RESULTS AND DISCUSSION}

\subsection{Total Rainfall}

The amount of rainfall, in general, increased with elevation, but some stations had totals above or below expected (Fig. 1). The stations Ceiba Dry I (CDI), Las Cabeza Dry (LCD), Río Grande (RG), Toro, and El Yunque Peak (YPC) consistently had lower accumulated rain than expected. When stations were grouped and averaged by elevation type, a more explicit relationship between rainfall and elevation unfolds. Through the ten years of measurements, LC stations had the least amount of rainfall, and UCFL stations had the highest amount of precipitation. The ratio of UCFL yearly precipitation over that of LC exhibits a range of 2.94-3.44, showing that UCFL stations receive substantially more rainfall (about 3 times more) that LC stations. In a climate change scenario, where precipitation is expected to decrease, areas that receive large amounts of rainfall can be especially vulnerable to these changes as many species that inhabit these ecosystems are 


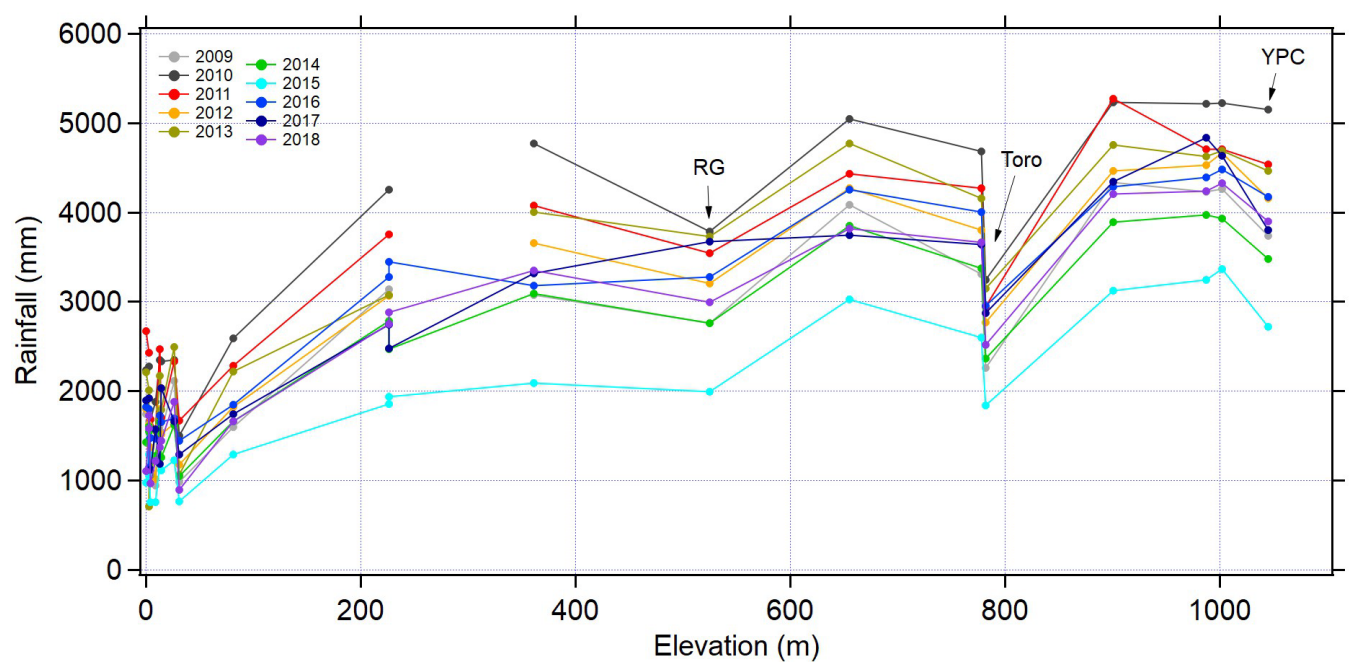

Fig. 1. Annual averages of rainfall as a function of elevation for all sampling sites.

accustomed to these often-saturated conditions. These results also highlight the relative importance of these high-altitude ecosystems in the water budget of the whole ecosystem and human settlements that get their water supply from the precipitation generated there.

The stations with the lowest and highest accumulated rainfall varied during the measuring period. In 2009, 2011 and 2012, CDI was the driest station; in 2010, 2016, and 2018 it was LCD; and from 2013 to 2015 and 2017, it was Las Cabezas Mangle (LCM). Mount Britton (MB) station was the rainiest from 2009 to 2011 and 2013; Pico del Este (PEC) in 2012, 2015, 2016, and 2018; and Pico del Oeste (POC) in 2014 and 2017. The stations ELV, Toro, and YPC departed from the altitudinal trend, suggesting that slope, distance from the coast, and position of the station regarding the prevailing winds, were the factors responsible for this pattern (Fig. 1). In the case of YPC, which is the highest-elevation station, a possible explanation for the deviation from the trend could be that, in some instances, rain develops below the station level. For ELV and Toro, the location could be an important factor as these are the stations further west and more prone to experience the rain shadow effect.

A monthly profile was done for each station to identify seasonal patterns by elevation group (Fig. 2). This profile shows that May is the month with the highest amount of rain followed by a sharp decrease in rainfall in June, while February is the driest month. This pattern was consistent for all elevation categories, but it was more pronounced with increasing elevation. For LC and LI stations, the first four months of the year are the driest ones, but this pattern does not hold in $\mathrm{LM}, \mathrm{CFL}$, and UCFL.

Previous studies at the Luquillo Mountains reported that rainfall has been increasing in the last decades. Torres-Valcárcel et al. (2014) found an increase in precipitation for the whole island of Puerto Rico in the 1990-2007 period. This finding is supported by the study presented in Van Beusekom et al. (2015), where they found an increase in precipitation as a function of time from 2001 to 2013. However, our results show a tendency for rainfall to decrease in the period 20092018 , except for LM. The decreasing tendency was mainly driven by reduced precipitation during the 2010-2015 period. The LC stations registered the lowest decrease in rainfall $\left(-25 \mathrm{~mm} \mathrm{y}^{-1} ;-2.3 \%\right.$; $\left.r^{2}=0.32\right)$ and the UCFL stations had the highest decrease in rainfall $\left(-85 \mathrm{~mm} \mathrm{y}^{-1} ;-2.3 \% ; \mathrm{r}^{2}=\right.$ $0.45)$, while $L M$ elevation type saw an increase in precipitation $\left(+25 \mathrm{~mm} \mathrm{y}^{-1} ; 1.1 \% ; \mathrm{r}^{2}=0.18\right)$. The tendency is clearer from 2008 to 2015, where all elevations saw a decrease in precipitation (-70, $-120,-90,-168,-225 \mathrm{~mm} \mathrm{y}^{-1}$ from LC to UCFL; $\mathrm{r}^{2}=0.51-0.70$ ), accentuated by a severe drought that took place in summer of 2015. The decreasing trend is then interrupted in 2017 because of the high amount of precipitation caused by Hurricane María. While our dataset is limited for analyzing climate trends, we can combine these observations to gauge how this variable is behaving as a function of time, as well as analyze short-term trends. The short-term trend seen in this study adjust to predictions of decreased precipitation in tropical forests as a consequence of climate change that have not been seen in previous studies for the Luquillo Mountains. While 


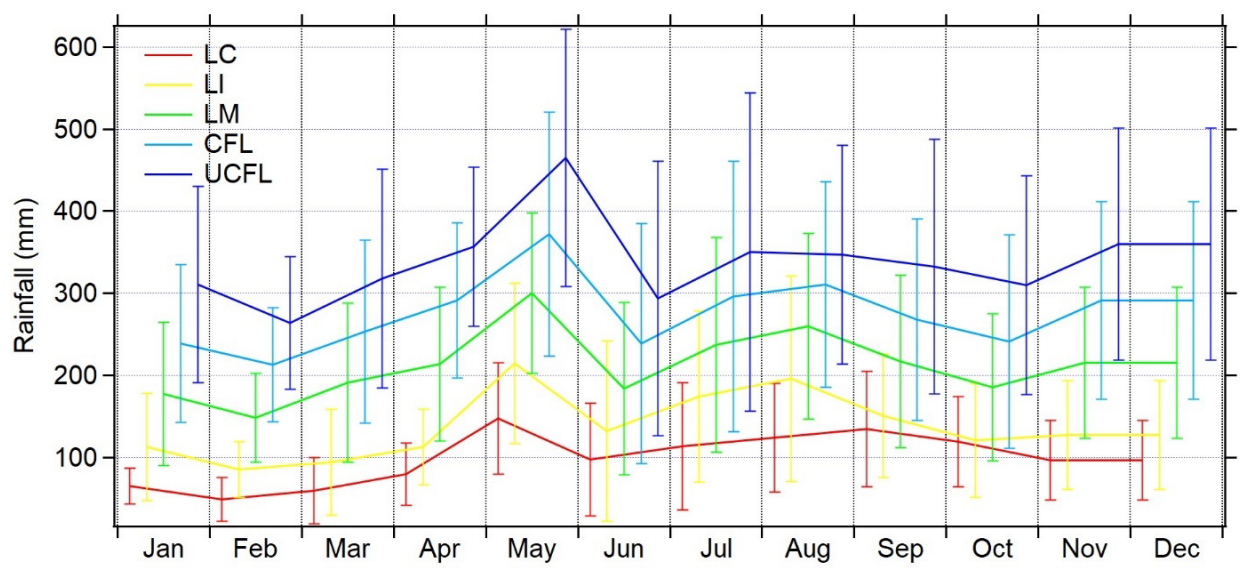

Fig. 2. Monthly profile of rainfall by elevation type. Error bars correspond to standard deviation. Lines are slightly offset for easier viewing.

a richer dataset is required to assess changes in climatic patterns, short-term trends can highlight important features that deserves further observation.

\section{$3.2 \mathrm{pH}$ of Rainfall Samples}

The $\mathrm{pH}$ had no relationship with elevation or rainfall volume, and in most instances, it remained within 5-6 for all elevation groups. The accepted value of unpolluted rainwater is 5.6 (Manahan, 2000), slightly acidic because of the carbon dioxide-carbonic acid equilibrium reaction that takes place in the atmosphere/water interface. A pH lower or higher than this value could be influenced by acidic species from anthropogenic pollution, or by neutralizing species, like those found in mineral dust.

\subsection{Ionic Composition of Rainfall Samples}

The mean annual weighted total ionic concentration was studied as a function of time and grouped by elevation group. It showed that there was a tendency for higher ionic concentrations in the lowland stations, but it was not consistent through time. This relationship is tied up with increasing rainfall with elevation, which promotes a higher washout rate and a lower concentration of ions in the atmosphere and a more significant dilution caused by a higher volume of rainwater. Charge balance was examined as the slope of anions as a function of cations for all stations. Most stations had a slope higher than 1 , which means there was a higher anionic concentration than cations. A deviation from 1 suggests the presence of ions in the samples that the analytical procedure is unable to detect, which could be organic ions. The concentration of hydronium was calculated from $\mathrm{pH}$ measurements to identify if this was one of the missing cations. Still, it did not account for the lower concentration of cations relative to anions. The $p$-value for these regressions with a confidence interval of $95 \%$ was smaller than 0.0001 for all stations.

Ionic concentration had a negative exponential relationship to rainfall, shown in Fig. 3. Pearson regression coefficient for the yearly values suggests that there is an inverse relationship between these variables for all years $\left(r^{2}=-0.66\right.$ to $\left.-0.86 ; n=159\right)$ except for year $2013\left(r^{2}=-0.29 ; n=20\right)$. The poor relationship in 2013 is due to a value with low ionic concentrations, that if omitted, improves the linear regression to $r^{2}=-0.90$. The concentration of ions is expected to decrease with an increasing volume of rain due to dilution and increased atmospheric particle washout, which validates the inverse relationship. The dilution effect followed a log-log linear relationship, and the $p$-values for all the regression coefficients were below 0.005 except for 2013, where it was 0.211 . Regression coefficients reveal that the tightness of this relationship is not constant and that large differences can occur. Most of these regression lines fall above the pure dilution line, suggesting that ionic concentration is the dominant feature in the dilution process.

\subsection{Seasonal Variation of Rainfall and Ionic Composition}

The island of Puerto Rico is mainly affected by three aerosol types, marine, crustal, and 


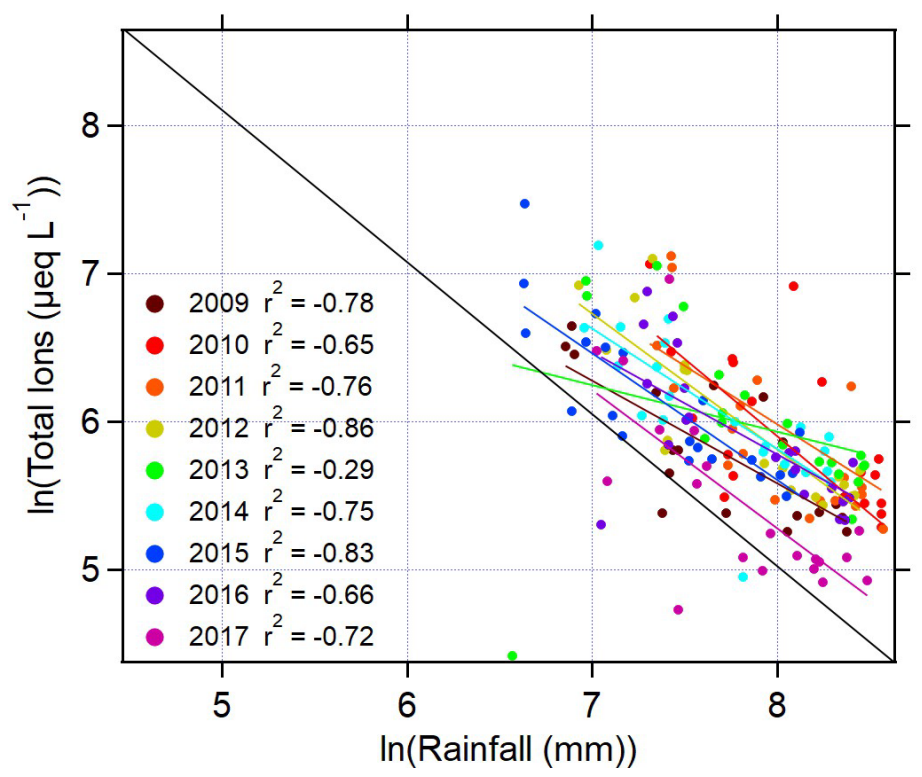

Fig. 3. Linear regression analysis of the natural logarithm of total ionic concentration as a function of the natural logarithm of rainfall.

anthropogenic, with $\mathrm{Na}^{+}, \mathrm{Ca}^{2+}$, and $\mathrm{SO}_{4}{ }^{2-}$ being the proxy ions used for identifying the influence of these aerosols (Stallard and Murphy, 2012; McClintock et al., 2019). However, the presence of $\mathrm{Ca}^{2+}$, and $\mathrm{SO}_{4}{ }^{2-}$ is not constant throughout the year and depends on seasonal patterns that transport aerosols from different sources. Sodium and sulfate ion concentrations were high during the first months of the year (January-April), which corresponds to the months with generally less rainfall (Fig. 4). The increase in sulfate concentration is considerable during these months, particularly in lowland coastal, lowland interior, and lower montane stations, which could be caused by an enrichment of non-sea-salt sulfate transported in anthropogenic aerosols from the eastern United States by cold fronts. A bump in concentrations of the three ions is seen during the summer months of June-August, more drastically seen in the $\mathrm{Ca}^{2+}$ concentration. The cause of this could be an enrichment of non-sea-salt calcium transported from the African continent by the trade winds and the position of the ITCZ.

Since, in addition to the predominant $\mathrm{Na}^{+}$and $\mathrm{Cl}^{-}$, both $\mathrm{Ca}^{2+}$ and $\mathrm{SO}_{4}{ }^{2-}$ are found in sea-salt (ss) particles, we assessed the marine influence of these ions per station calculating their Pearson correlation with $\mathrm{Na}^{+}$(Table 2). A high correlation coefficient $(>0.7)$ was found between $\mathrm{Na}^{+}$and $\mathrm{Cl}^{-}$in 17 of the 21 stations, suggesting both these ions come from the same source for all stations, which is marine sea-salt particles. On the other hand, $\mathrm{Na}^{+}$and $\mathrm{Ca}^{2+}$ were highly correlated in only one station (CDI), suggesting there is an important contribution of calcium from non-marine sources, the most important one being mineral dust from Africa. $\mathrm{Na}^{+}$and $\mathrm{SO}_{4}{ }^{2-}$ were highly correlated in 13 out of 21 stations, suggesting that there is a substantial contribution of sulfate ions from marine sources. There is also a small but non-negligible contribution from non-marine sources, which could be the contribution of anthropogenic pollution transported with cold fronts in the winter months.

Pearson correlation factor was analyzed for $\mathrm{Na}^{2+}$ and the non-sea-salt (nss) fraction of $\mathrm{Ca}^{2+}$ and $\mathrm{SO}_{4}{ }^{2-}$ (Table 2). In some cases, especially in the lower stations, the correlation of $\mathrm{Na}^{2+}$ with nss$\mathrm{Ca}^{2+}$ was stronger than that of $\mathrm{Na}^{2+}$ with total $\mathrm{Ca}^{2+}$. While $\mathrm{Na}^{2+}$ is mainly a marine aerosol, it is important to consider that it is also present in crustal sources, and this can be a possible explanation for this result. For higher-elevation stations (LM, CFL, UCFL), the relationship of $\mathrm{Na}^{2+}$ with nss- $\mathrm{Ca}^{2+}$ was weaker than that of $\mathrm{Na}^{2+}$ with total $\mathrm{Ca}^{2+}$. The weaker relationship could indicate that air masses containing crustal aerosols are less likely to reach higher-elevation stations. The relationship of $\mathrm{Na}^{2+}$ with nss- $\mathrm{SO}_{4}{ }^{2-}$ was almost always weaker (19 out of 21 stations) than that of $\mathrm{Na}^{2+}$ with total nss- $\mathrm{SO}_{4}{ }^{2-}$ and in cases where it was higher, it was only slightly (<3\% difference). This shows that $\mathrm{Na}^{2+}$ and nss- $\mathrm{SO}_{4}{ }^{2-}$ have very distinct sources and that sources of $\mathrm{ss}-\mathrm{SO}_{4}{ }^{2-}$ and nss- $\mathrm{SO}_{4}{ }^{2-}$ can be easily distinguished. 


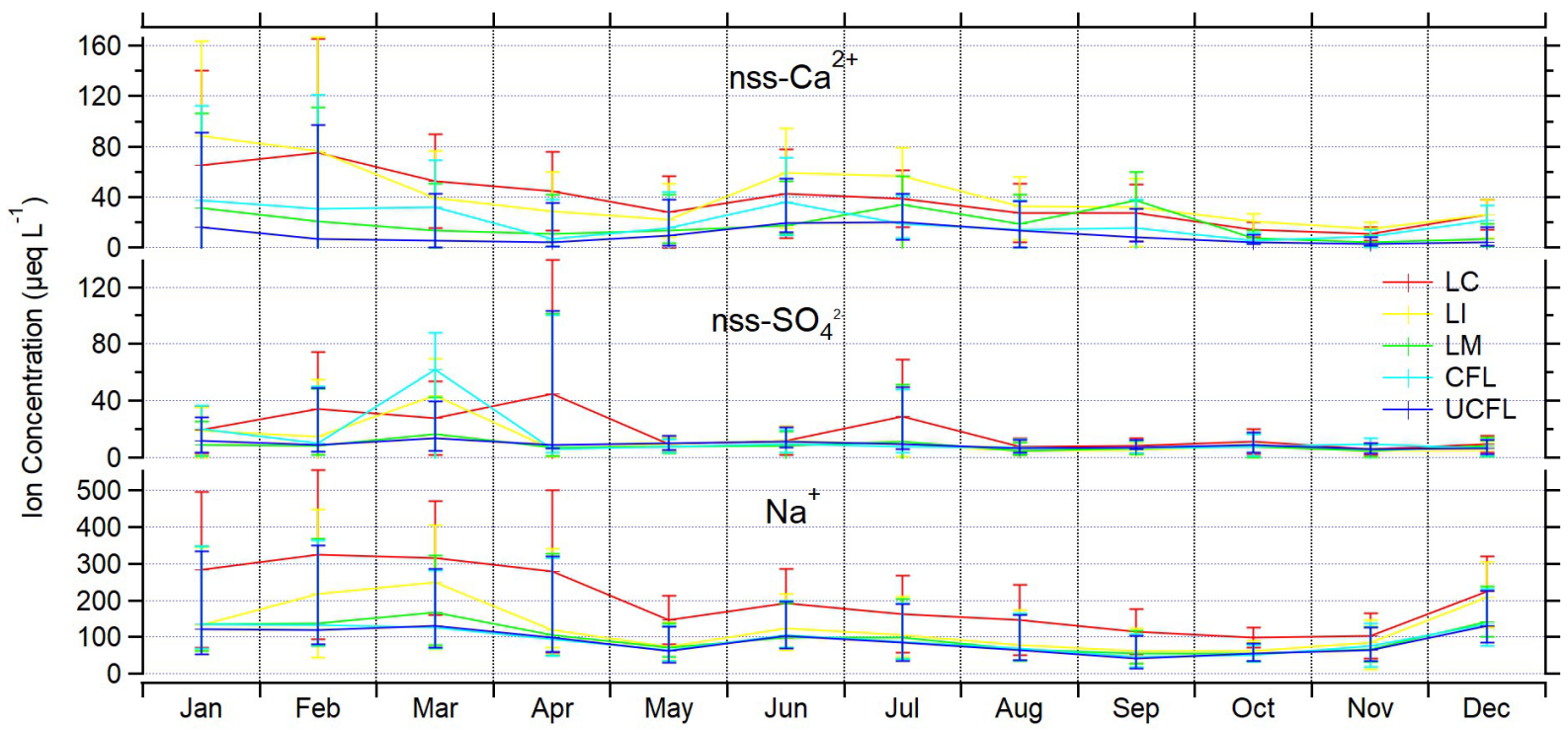

Fig. 4. Monthly profile of calcium, sulfate, and sodium concentration at different elevation types.

Table 2. Pearson correlation factor for different ions. Values in bold represent highly significant correlation ( $>0.7)$. Values in parentheses represent correlation with non-sea-salt fraction of the species.

\begin{tabular}{|c|c|c|c|c|}
\hline \multirow{2}{*}{ Station } & \multicolumn{3}{|c|}{ Pearson correlation factor } & \multirow{2}{*}{$\mathrm{n}$} \\
\hline & $\mathrm{Na}^{+}$vs. $\mathrm{Cl}^{-}$ & $\mathrm{Na}^{+}$vs. $\mathrm{Ca}^{2+}\left(\mathrm{nss}-\mathrm{Ca}^{2+}\right)$ & $\mathrm{Na}^{+}$vs. $\mathrm{SO}_{4}{ }^{2-}\left(\mathrm{nss}-\mathrm{SO}_{4}{ }^{2-}\right)$ & \\
\hline PDM & 0.49 & $0.445(0.599)$ & $0.496(0.095)$ & 64 \\
\hline $\mathrm{H}$ & 0.781 & $0.312(0.424)$ & $0.745(0.285)$ & 59 \\
\hline SS\#2 & 0.948 & $0.332(0.496)$ & $0.749(0.759)$ & 32 \\
\hline LCM & 0.718 & $0.358(0.344)$ & $0.634(0.154)$ & 63 \\
\hline CDI & 0.949 & $0.784(0.430)$ & $0.779(0.209)$ & 63 \\
\hline CDII & 0.693 & $0.584(0.469)$ & $0.703(0.347)$ & 62 \\
\hline LCD & 0.948 & 0.397 (0.799) & $0.179(0.126)$ & 61 \\
\hline Ford & 0.699 & $0.187(0.582)$ & $0.649(0.194)$ & 65 \\
\hline$J B$ & 0.737 & $0.35(0.260)$ & $0.592(0.499)$ & 65 \\
\hline SJ & 0.569 & $0.288(0.210)$ & $0.792(0.398)$ & 66 \\
\hline S4 & 0.891 & $0.021(-0.031)$ & $0.712(-0.027)$ & 70 \\
\hline S4\#2 & 0.851 & $0.113(-0.108)$ & $0.65(-0.434)$ & 38 \\
\hline ELV & 0.907 & $0.134(0.090)$ & $0.732(-0.044)$ & 70 \\
\hline RG & 0.922 & $0.158(0.231)$ & 0.599 (0.617) & 70 \\
\hline NIDO & 0.901 & $0.169(0.181)$ & $0.778(0.413)$ & 70 \\
\hline $\mathrm{CO}$ & 0.896 & $0.144(0.093)$ & $0.802(0.167)$ & 70 \\
\hline TORO & 0.911 & $0.564(0.413)$ & $0.609(-0.138)$ & 70 \\
\hline $\mathrm{MB}$ & 0.895 & $0.246(0.176)$ & $0.751(0.188)$ & 70 \\
\hline POC & 0.833 & $0.145(0.036)$ & $0.757(0.097)$ & 70 \\
\hline PEC & 0.907 & $0.089(0.028)$ & $0.785(0.096)$ & 69 \\
\hline YPC & 0.92 & $0.248(0.157)$ & $0.768(0.377)$ & 68 \\
\hline
\end{tabular}

\subsection{Variations of Rainfall and Ionic Composition with Elevation}

The ionic mass deposition per unit area for all measured ions was determined for each elevation group, and the yearly average (Table 3). As expected, $\mathrm{Cl}^{-}$and $\mathrm{Na}^{+}$had the highest mass deposition for all stations, followed by $\mathrm{K}^{+}, \mathrm{SO}_{4}{ }^{2-}, \mathrm{Ca}^{2+}, \mathrm{PO}_{4}{ }^{3-}, \mathrm{Mg}^{2+}$, and $\mathrm{NH}_{4}{ }^{+}$. Mass deposition of $\mathrm{NO}_{3}{ }^{-}, \mathrm{F}^{-}, \mathrm{Br}^{-}$, and $\mathrm{Li}^{+}$was almost negligible and thus not further analyzed. Mass deposition of $\mathrm{Cl}^{-}$, $\mathrm{SO}_{4}{ }^{2-}, \mathrm{Na}^{+}$and $\mathrm{Mg}^{2+}$ increased with elevation, and that of $\mathrm{NH}_{4}{ }^{+}$and $\mathrm{Ca}^{2+}$ increased with elevation except for the UCFL elevations. The increase of mass deposition with elevation can be explained by the rise of rain amount, which effectively deposits ions from the atmosphere into the surface. 
Table 3. Yearly ionic mass deposition per unit area for the different elevation groups.

\begin{tabular}{|c|c|c|c|c|c|c|c|c|c|c|c|c|}
\hline \multirow{2}{*}{$\begin{array}{l}\text { Elevation } \\
\text { group }\end{array}$} & \multicolumn{12}{|c|}{ Ionic deposition $\left(\mathrm{kg} \mathrm{ha}^{-1} \mathrm{y}^{-1}\right)$} \\
\hline & $\mathrm{Fl}^{-}$ & $\mathrm{Cl}^{-}$ & $\mathrm{SO}_{4}{ }^{2-}$ & $\mathrm{Br}^{-}$ & $\mathrm{NO}_{3}^{-}$ & $\mathrm{PO}_{4}^{3-}$ & $\mathrm{Li}^{+}$ & $\mathrm{Na}^{+}$ & $\mathrm{NH}^{4+}$ & $\mathrm{K}^{+}$ & $\mathrm{Mg}^{2+}$ & $\mathrm{Ca}^{2+}$ \\
\hline LC & 0.290 & 34.0 & 7.64 & 0.280 & 0.140 & 3.33 & 0.070 & 17.8 & 2.06 & 8.10 & 2.91 & 4.38 \\
\hline LI & 0.200 & 32.9 & 8.73 & 0.180 & 0.240 & 3.49 & 0.077 & 16.2 & 3.07 & 12.9 & 2.55 & 5.84 \\
\hline LM & 0.238 & 44.0 & 10.6 & 0.198 & 0.238 & 2.69 & 0.188 & 25.9 & 3.39 & 7.22 & 3.40 & 5.19 \\
\hline CFL & 0.237 & 61.2 & 16.6 & 0.263 & 0.310 & 5.50 & 0.173 & 31.9 & 4.44 & 7.05 & 4.28 & 7.01 \\
\hline UCFL & 0.200 & 70.4 & 18.8 & 0.218 & 0.515 & 4.74 & 0.225 & 40.0 & 2.38 & 3.47 & 4.90 & 5.93 \\
\hline
\end{tabular}

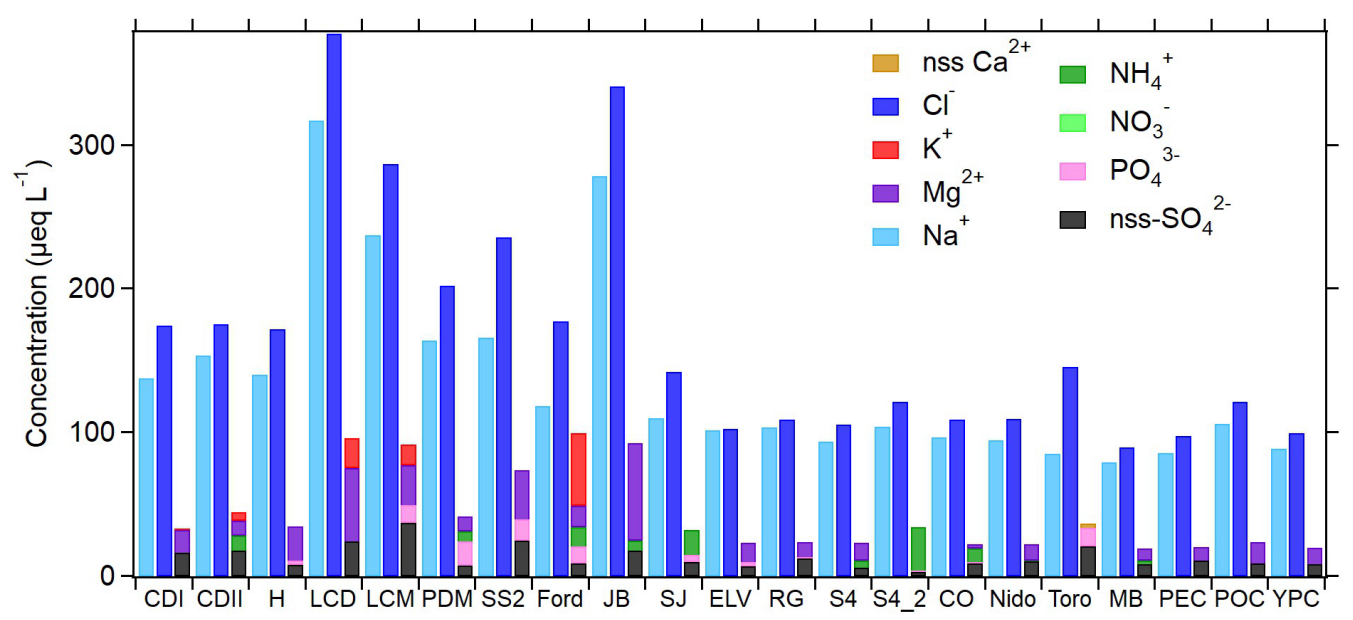

Fig. 5. Yearly weighted mean ionic concentration for each station.

Mass deposition of $\mathrm{PO}_{4}{ }^{3-}$ and $\mathrm{K}^{+}$did not have a clear pattern with elevation. Still, the deposition of $\mathrm{K}^{+}$at the CFL and UCFL decreased, a behavior also seen by Medina et al. (2013). High inputs of $\mathrm{K}^{+}$and $\mathrm{Mg}^{2+}$ can be attributed to both marine and crustal sources (Valle-Díaz et al., 2016), while $\mathrm{PO}_{4}{ }^{3-}$ can be attributed to crustal sources (Pett-Ridge, 2009). These results show that marine and crustal sources are the main contributors to the ionic load and deposition to the Luquillo Mountains and that they are an important source of nutrients to the ecosystem.

The annual weighted mean concentration of ions was analyzed as a function of elevation (Fig. 5). This plot shows that the ionic concentration at lower stations does not follow a clear trend but rather erratic movements. Similarly, the annual amount of rainfall did not follow a clear pattern. However, while the elevation between these stations is not large, their geographical location and exposure to the northeasterly trade winds are vastly different. The stations CDI, CDII, $\mathrm{H}$, and PDM are located on the southeastern coast, while the stations LCD and LCM are situated in the most northeastern part of the island. This suggests that the trade winds and precipitation will more directly influence the latter two stations from marine cumulus clouds than those in the southeastern region. However, this is not necessarily the case as only the station CDII received less precipitation than those in the northeast. There is a clear difference in the total concentration of ions for these stations, with those located on the northeastern coast receiving more ions than those in the southeastern coast. The higher concentration of sea-salt ions $\left(\mathrm{Na}^{+}\right.$, $\mathrm{Cl}^{-}, \mathrm{K}^{+}$and $\mathrm{Mg}^{2+}$ ) in the northeastern coast stations suggests that the influence of the trade winds could be resulting in higher wind speeds that are dragging more marine aerosols with them. Also, these stations had the largest concentrations of $\mathrm{nss}_{-} \mathrm{SO}_{4}{ }^{2-}$ because of the nearby mangroves that cause anoxic conditions in the ground and high sulfur content.

The lowland interior station Ford had the largest concentrations of $\mathrm{K}^{+}$, and high concentrations of $\mathrm{PO}_{4}{ }^{3-}$ and $\mathrm{NO}_{3}{ }^{-}$, suggesting that these could be the results nearby manufacturing facilities and agricultural activity. The station JB had the highest values of $\mathrm{nss}_{-} \mathrm{SO}_{4}{ }^{2-}$ from the lowland interior stations, which is expected because this station is in the highly populated metropolitan area and more exposed to the aerosols emitted from anthropogenic activity.

Stations in the LM, CFL and UCFL areas showed a more consistent trend of increasing 
precipitation and decreasing ionic concentration. The clearest exceptions to this trend were the ELV and Toro stations that had a noticeably lower amount of rainfall than the rest of the stations in its altitude classification. Interestingly, these stations are in the western part of the mountains. Since the mountain formation is close to the coast and has a steep elevation slope, they are prone to form precipitation due to orographic lifting of air masses moved by the trade winds. Those stations in the western part of the mountain will experience the rain shadow effect, where most of the precipitation forms in the eastern face of the mountain. The Toro station is further west than the rest of the mountain stations and thus experiences this effect more, reflected in the reduced precipitation and increased ionic concentration compared to the rest of the stations at comparable altitudes. This station also presented higher nss- $\mathrm{SO}_{4}{ }^{2-}$ and $\mathrm{PO}_{4}{ }^{3-}$ than the rest of the mountain stations, suggesting that there could be emissions from primary biogenic aerosols being emitted in the forest and reaching this station. Anthropogenic activity in this area is unlikely since it is part of a protected area where no development is allowed. Another exception to this trend is the UCFL stations, where the concentration of aerosols exponentially increased for the $M B, P E C$ and POC stations and drops for the YPC station. The ions that followed this countertrend were the marine aerosols $\mathrm{Na}^{+}, \mathrm{Cl}^{-}$and $\mathrm{Mg}^{2+}$, along with $\mathrm{NO}_{3}{ }^{-}$and $\mathrm{PO}_{4}{ }^{3-}$. An explanation for this behavior was not found. A possible reason for the decrease in precipitation at the YPC station relative to the trend that the other stations in its altitude range follow could be that this station is slightly higher than where most precipitation forms and being excluded from some of the rain events.

The ionic concentration results from this study were higher for all species than those reported in Medina et al. (2013). However, our dataset comprises a more extended period and is more representative of the average yearly deposition at the different locations, as well as including periods of abnormally low rainfall, as in the case of 2015, when concentrations increase. Asbury et al. (1994) determined ionic concentrations at Pico del Este that were 2.5-5.5 times higher than the concentration determined in this study for UCFL stations, like the observation made in Medina et al. (2013). The results from Gioda et al. (2011) from seven rain events at Pico del Este agree well with ours, although slightly lower for most ions except $\mathrm{NO}_{3}{ }^{-}$and $\mathrm{SO}_{4}{ }^{2-}$, which we attribute is because this sampling took place during the winter period when cold fronts carrying anthropogenic pollution are common. Gioda et al. (2013) analyzed ions in rainwater at three locations of the Luquillo Mountains: El Verde, Bisley, and Pico del Este. Our results of ELV agree well with their results for the same El Verde area, except for the case of $\mathrm{K}^{+}$and $\mathrm{NH}_{4}{ }^{+}$, for which we got an average concentration that was higher by about a factor of 4 and 10 , respectively, and $\mathrm{NO}_{3}^{-}$, where we got a concentration that was lower by about a factor of 12. In Pico del Este, we got concentrations that were lower by about a factor of 2 for $\mathrm{Ca}^{2+}, \mathrm{Mg}^{2+}, \mathrm{K}^{+}$, and $\mathrm{SO}_{4}{ }^{2-}$; slightly lower concentrations for $\mathrm{Na}^{+}$and $\mathrm{Cl}^{-}$; and drastically lower concentration for $\mathrm{NO}_{3}^{-}$; only $\mathrm{NH}_{4}{ }^{+}$agreed well in both studies. Differences in concentrations determined at PEC may have arisen from not being in the same location and being possibly exposed to different weather conditions, as well as by different sample collection and analysis methodology. A more recent study of a 20-year record of rain chemistry at Bisley and El Verde by McClintock et al. (2019) showed concentrations of nss-Ca ${ }^{2+}$ lower than those presented here.

A considerable difference from our work is that most of these studies collected 1-week samples or samples by rain events for their analysis, while our samples were from 2 weeks. The additional time in the field can cause differences in the ionic concentrations as they are exposed to daily changes in temperature, and as redox reactions take place. We expect this effect to be higher in lower-elevation station as temperatures decrease with elevation. Also, these samples are more prone to have enhanced concentration of ions due to dry deposition of aerosol particles, which would explain the higher concentration of specific ions in this study in comparison to those who have a shorter hold time in the field. Medina et al. (2013) estimated an enhancement of up to $40 \%$ in $\mathrm{Na}^{+}$and $\mathrm{Cl}^{-}$concentrations and up to $60 \%$ in $\mathrm{Mg}^{2+}$ and $\mathrm{Ca}^{2+}$ concentration in comparison to the National Atmospheric Deposition Program (NADP) samples collected at lower montane stations.

When the results from this study are compared with those of other rainforest, the effect of the air mass influence on the rain chemistry becomes more apparent. A study done in West Africa by Sigha-Nkamdjou et al. (2003) reported that their most abundant inorganic ions were $\mathrm{NH}_{4}{ }^{+}$and $\mathrm{NO}_{3}{ }^{-}$, corresponding to biomass burning aerosols, and low abundance of $\mathrm{Na}^{+}$and $\mathrm{Cl}^{-}$, that were the most 
abundant ions in our study. Concentrations of $\mathrm{NH}_{4}{ }^{+}$and $\mathrm{NO}_{3}{ }^{-}$were about 3 times higher and 6 times lower, respectively in our study while concentrations of $\mathrm{Na}^{+}$and $\mathrm{Cl}^{-}$were substantially higher. $\mathrm{A}$ study done in a tropical forest in eastern China influenced by emissions from motor vehicles by Niu et al. (2017) found that $\mathrm{SO}_{4}{ }^{2-}$ and $\mathrm{NO}_{3}{ }^{-}$accounted for about $88 \%$ of their inorganic ion composition. The volume-weighted mean values for both of these species were 49.8 and $32.6 \mu \mathrm{eq} \mathrm{L}^{-1}$, respectively, that were $25 \%$ and $97 \%$ larger than the maximum concentration seen in this study.

Our results are much more comparable to those found in Lesack and Melack (1991) where rain chemistry was studied in the tropical forest of La Selva, Costa Rica. This study found that the largest ionic influence in rainwater was from marine sources, although our study reported larger concentrations of marine aerosols. We also saw an overall higher concentration of all ions than what Lesack and Melack (1991) reported, which could be due to differences in location and sampling methodology, which can also explain differences with the other studies.

\section{CONCLUSION}

We analyzed a rich multiyear (2009-2018) dataset for the rainfall and rainwater chemistry recorded by 21 stations situated along the elevation gradient of the Luquillo Mountains. Contrary to the measurements reported by other studies (Torres-Valcárcel et al., 2014; Van Beusekom et al., 2015), the rainfall recorded at the majority of the stations decreased from 2009 through 2014 before increasing for the next 3 years. Reduced precipitation may produce a negative outcome for this tropical forest, which depends on high water input all year long, and although the limited time frame of this study precluded the identification of a climatic pattern, the results may aid decision making in forest management, especially for preserving biodiversity in the most vulnerable ecosystems.

A positive correlation was found between the elevation and the rainfall, but a few of the stations proved to be exceptions to this trend, which suggests that changes in rainfall may affect higheraltitude ecosystems (e.g., CFL and UCFL), such as the elfin cloud forest in the uppermost parts of the Luquillo Mountains, to a greater degree. Additionally, we observed an inverse exponential relationship between the total ionic concentration and the total volume of the rainwater, despite the lack of an obvious link between the latter and the $\mathrm{pH}$.

The ionic composition, being heavily influenced by transported aerosols, exhibited clear seasonal patterns. Although marine aerosols were consistently present all year, crustal aerosols-particularly those originating from African dust, which serve as a major source of micro- and macronutrients, including calcium and phosphate, along the elevation gradient-were more abundant during summer, and anthropogenic aerosols were more abundant during winter.

Finally, our findings somewhat contradicted the expectation that the rainfall increases, and the rainwater's ionic concentration decreases with the elevation. Because the complex topography of the Luquillo Mountains significantly influences cloud formation and precipitation patterns, the elevation is not the sole predictor of these variables. However, owing to the effect of the rain shadow, the side of the mountain on which a station was situated proved to be a major factor, with the sites on west-facing slopes typically recording lower rainfall and higher ionic concentrations than those at comparable altitudes on east-facing slopes. Overall, though, the mass deposition of most of the ionic species generally rose with the elevation, confirming the essential role of rain in montane ecosystems as a primary source of both water and nutrients.

\section{ACKNOWLEDGMENTS}

The authors thank Carlos Estrada, Samuel Moya, Humberto Robles, and Carlos Torrens for assisting with field data collection, and personnel of the International Institute of Tropical Forestry Chemistry Laboratory for water chemistry analyses. The authors also acknowledge Ariel E. Lugo for reviewing an earlier draft of the manuscript. This research was funded by the Luquillo Critical Zone Observatory (National Science Foundation Grant EAR-1331841), Luquillo Long-Term Ecological Research Site (National Science Foundation Grant DEB-1239764), and the USDA Forest Service. The authors acknowledge the USDA Natural Resources Career Program (Grant 201738422-27131) for student financial support during this project. All research at the International 
Institute of Tropical Forestry is done in collaboration with the University of Puerto Rico. Any use of trade, product, or firms' names is for descriptive purposes only and does not imply endorsement by the U.S. government.

\section{DISCLAIMER}

Reference to any companies or specific commercial products does not constitute an endorsement from authors.

\section{DATA AVAILABILITY}

The data used for this study is available at: https://doi.org/10.2737/RDS-2021-0013

\section{REFERENCES}

Allan, J.D., Baumgardner, D., Raga, G.B., Mayol-Bracero, O.L., Morales-García, F., García-García, F., Montero-Martínez, G., Borrmann, S., Schneider, J., Mertes, S., Walter, S., Gysel, M., Dusek, U., Frank, G.P., Krämer, M. (2008). Clouds and aerosols in Puerto Rico - A new evaluation. Atmos. Chem. Phys. 8, 1293-1309. https://doi.org/10.5194/acp-8-1293-2008

Asbury, C.E., McDowell, W.H., Trinidad-Pizarro, R., Berrios, S. (1994). Solute deposition from cloud water to the canopy of a puerto rican montane forest. Atmos. Environ. 28, 1773-1780. https://doi.org/10.1016/1352-2310(94)90139-2

Brokaw, N., Crowl, T.A., Lugo, A.E., McDowell, W.H., Scatena, F.N., Waide, R.B., Willig, M.R. (2012). A Caribbean forest tapestry: the multidimensional nature of disturbance and response. Oxford University Press, New York.

García-Martinó, A.R., Warner, G.S., Scatena, F.N., Civco, D.L. (1996). Rainfall, runoff, and elevation relationships in the Luquillo Mountains of Puerto Rico. Caribb. J. Sci. 32, 41-65.

Gioda, A., Mayol-Bracero, O.L., Morales-García, F., Collett, J., Decesari, S., Emblico, L., Facchini, M.C., Morales-De Jesús, R.J., Mertes, S., Borrmann, S., Walter, S., Schneider, J. (2009). Chemical composition of cloud water in the puerto rican tropical trade wind cumuli. Water. Air Soil Pollut. 200, 3-14. https://doi.org/10.1007/s11270-008-9888-4

Gioda, A., Reyes-Rodríguez, G.J., Santos-Figueroa, G., Collett, J.L., Decesari, S., Ramos, M.D.C.K.V., Bezerra Netto, H.J.C., De Aquino Neto, F.R., Mayol-Bracero, O.L. (2011). Speciation of watersoluble inorganic, organic, and total nitrogen in a background marine environment: Cloud water, rainwater, and aerosol particles. J. Geophys. Res. 116, D05203. https://doi.org/10.1029 /2010JD015010

Gioda, A., Mayol-Bracero, O.L., Scatena, F.N., Weathers, K.C., Mateus, V.L., McDowell, W.H. (2013). Chemical constituents in clouds and rainwater in the Puerto Rican rainforest: Potential sources and seasonal drivers. Atmos. Environ. 68, 208-220. https://doi.org/10.1016/j.atmosen v.2012.11.017

González, G., Willig, M.R., Waide, R.B. (2013). Ecological gradient analyses in a tropical landscape. Ecological Bulletins 54. Wiley-Blackwell, Hoboken, NJ. p. 252.

Gould, W.A., González, G., Rivera, G.C. (2006). Structure and composition of vegetation along an elevational gradient in Puerto Rico. J. Veg. Sci. 17, 653-664. https://doi.org/10.1111/j.16541103.2006.tb02489.x

Heartsill-Scalley, T., Scatena, F.N., Estrada, C., McDowell, W.H., Lugo, A.E. (2007). Disturbance and long-term patterns of rainfall and throughfall nutrient fluxes in a subtropical wet forest in Puerto Rico. J. Hydrol. 333, 472-485. https://doi.org/10.1016/j.jhydrol.2006.09.019

Lesack, L.F.W., Melack, J.M. (1991). The deposition, composition, and potential sources of major ionic solutes in rain of the central Amazon Basin. Water Resour. Res. 27, 2953-2977. https://doi.org/10.1029/91WR01946

Lugo, A.E., Waide, R.B., Willig, M.R., Crowl, T.A., Scatena, F.N., Thompson, J., Silver, W.L., McDowell, W.H., Brokaw, N. (2012). Ecological Paradigms for the Tropics, in: Brokaw, N., Crowl, T., Lugo, A., McDowell, W., Scatena, F., Waide, R., Willig, M. (Eds.), A Caribbean Forest 
Tapestry, Oxford University Press, pp. 3-41. https://doi.org/10.1093/acprof:osobl/978019533 4692.003.0001

Manahan, S. (2000). Fundamentals of Environmental Chemistry, Second Edition, Fundamentals of Environmental Chemistry, Second Edition. CRC Press. https://doi.org/10.1201/9781420056716

Martens, C.S., Harriss, R.C. (1973). Chemistry of aerosols, cloud droplets, and rain in the Puerto Rican marine atmosphere. J. Geophys. Res. 78, 949-957. https://doi.org/10.1029/jc078i006p0 0949

McClintock, M.A., McDowell, W.H., González, G., Schulz, M., Pett-Ridge, J.C. (2019). African dust deposition in Puerto Rico: Analysis of a 20-year rainfall chemistry record and comparison with models. Atmos. Environ. 216, 116907. https://doi.org/10.1016/j.atmosenv.2019.116907

McDowell, W.H., Sánchez, C.G., Asbury, C.E., Ramos Pérez, C.R. (1990). Influence of sea salt aerosols and long range transport on precipitation chemistry at El Verde, Puerto Rico. Atmos. Environ. 24, 2813-2821. https://doi.org/10.1016/0960-1686(90)90168-M

Medina, E., González, G., Rivera, M.M. (2013). Spatial and temporal heterogeneity of rainfall inorganic ion composition in northeastern Puerto Rico. Ecollogical Bull. 54, 157-167.

Murphy, S.F., Stallard, R.F., Scholl, M.A., González, G., Torres-Sánchez, A.J. (2017). Reassessing rainfall in the Luquillo Mountains, Puerto Rico: Local and global ecohydrological implications. PLoS One 12, e0180987. https://doi.org/10.1371/journal.pone.0180987

Niu, Y., Li, X., Huang, Z., Zhu, C. (2017). Chemical characteristics and possible causes of acid rain at a regional atmospheric background site in eastern China. Air Qual. Atmos. Health 10, 971980. https://doi.org/10.1007/s11869-017-0486-8

Odum, H.T. (1970). Summary: An emerging view of the ecological system at El Verde. in: Odum, H.T. and Pigeon, R.F. (Eds.), ATropical Rain Forest. National Technical Information Service, Springfield, Virginia. pp. 277-281.

Pett-Ridge, J.C. (2009). Contributions of dust to phosphorus cycling in tropical forests of the Luquillo Mountains, Puerto Rico. Biogeochemistry 94, 63-80. https://doi.org/10.2307/20519864

Prospero, J.M., Lamb, P.J. (2003). African droughts and dust transport to the caribbean: Climate change implications. Science 302, 1024-1027. https://doi.org/10.1126/science.1089915

Prospero, J.M., Mayol-Bracero, O.L. (2013). Understanding the transport and impact of African dust on the Caribbean Basin. Bull. Am. Meteorol. Soc. 94, 1329-1337. https://doi.org/10.1175/ BAMS-D-12-00142.1

Sigha-Nkamdjou, L., Galy-Lacaux, C., Pont, V., Richard, S., Sighomnou, D., Lacaux, J.P. (2003). Rainwater chemistry and wet deposition over the equatorial forested ecosystem of Zoétélé (Cameroon). J. Atmos. Chem. 46, 173-198. https://doi.org/10.1023/A:1026057413640

Stallard, R.F., Murphy, S.F. (2012). Atmospheric Inputs to Watersheds of the Luquillo Mountains in Eastern Puerto Rico Water Quality and Landscape Processes of Four Watersheds in Eastern Puerto Rico, in: Murphy, Sheila F.; Stallard, R.F. (Ed.), Water Quality and Landscape Processes of Four Watersheds in Eastern Puerto Rico. pp. 89-109.

Torres-Valcárcel, Á., Harbor, J., González-Avilés, C., Torres-Valcárcel, A. (2014). Impacts of urban development on precipitation in the tropical maritime climate of puerto rico. Climate 2, 4777. https://doi.org/10.3390/cli2020047

Valle-Díaz, C.J., Torres-Delgado, E., Colón-Santos, S.M., Lee, T., Collett, J.L., McDowell, W.H., Mayol-Bracero, O.L. (2016). Impact of long-range transported african dust on cloud water chemistry at a tropical montane cloud forest in Northeastern Puerto Rico. Aerosol Air Qual. Res. 16, 653-664. https://doi.org/10.4209/aaqr.2015.05.0320

Van Beusekom, A.E., González, G., Rivera, M.M. (2015). Short-term precipitation and temperature trends along an elevation gradient in northeastern Puerto Rico. Earth Interact. 19, 1-33. https://doi.org/10.1175/EI-D-14-0023.1

Weathers, K.C., Likens, G.E., Herbert Bormannrbert, F., Bicknell, S.H., Bormann, B.T., Daube, B.C., Eaton, J.S., Galloway, J.N., Keene, W.C., Kimball, K.D., McDowell, W.H., Siccama, T.G., Smiley, D., Tarrant, R.A. (1988). Cloudwater chemistry from ten sites in North America. Environ. Sci. Technol. 22, 1018-1026. https://doi.org/10.1021/es00174a004 